\title{
Where microorganisms meet rocks in the Earth's Critical Zone
}

\author{
D. M. Akob and K. Küsel \\ Institute of Ecology, Friedrich Schiller University Jena, Dornburger Straße 159, 07743 Jena, Germany
}

Received: 12 February 2011 - Published in Biogeosciences Discuss.: 9 March 2011

Revised: 28 October 2011 - Accepted: 15 November 2011 - Published: 2 December 2011

\begin{abstract}
The Critical Zone (CZ) is the Earth's outer shell where all the fundamental physical, chemical, and biological processes critical for sustaining life occur and interact. As microbes in the $\mathrm{CZ}$ drive many of these biogeochemical cycles, understanding their impact on life-sustaining processes starts with an understanding of their biodiversity. In this review, we summarize the factors controlling where terrestrial CZ microbes (prokaryotes and micro-eukaryotes) live and what is known about their diversity and function. Microbes are found throughout the $\mathrm{CZ}$, down to $5 \mathrm{~km}$ below the surface, but their functional roles change with depth due to habitat complexity, e.g. variability in pore spaces, water, oxygen, and nutrients. Abundances of prokaryotes and micro-eukaryotes decrease from $10^{10}$ or $10^{7}$ cells g soil $^{-1}$ or rock $^{-1}$, or ml water ${ }^{-1}$ by up to eight orders of magnitude with depth. Although symbiotic mycorrhizal fungi and freeliving decomposers have been studied extensively in soil habitats, where they occur up to $10^{3}$ cells g soil ${ }^{-1}$, little is known regarding their identity or impact on weathering in the deep subsurface. The relatively low abundance of microeukaryotes in the deep subsurface suggests that they are limited in space, nutrients, are unable to cope with oxygen limitations, or some combination thereof. Since deep regions of the $\mathrm{CZ}$ have limited access to recent photosynthesis-derived carbon, microbes there depend on deposited organic material or a chemolithoautotrophic metabolism that allows for a complete food chain, independent from the surface, although limited energy flux means cell growth may take tens to thousands of years. Microbes are found in all regions of the $\mathrm{CZ}$ and can mediate important biogeochemical processes, but more work is needed to understand how microbial populations influence the links between different regions of the $\mathrm{CZ}$ and weathering processes. With the recent development of "omics" technologies, microbial ecologists have new methods that can be used to link the composition and function of in situ microbial communities. In particular, these methods can be used to search for new metabolic pathways that are
\end{abstract}

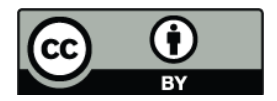

Correspondence to: K. Küsel (kirsten.kuesel@uni-jena.de) relevant to biogeochemical nutrient cycling and determine how the activity of microorganisms can affect transport of carbon, particulates, and reactive gases between and within $\mathrm{CZ}$ regions.

\section{The Critical Zone - where rocks meet life}

The Earth's Critical Zone (CZ) is the heterogeneous environment where complex interactions between rock, soil, water, air, and living organisms regulate the availability of lifesustaining resources (NRC, 2001). It is a huge region, ranging from the outer extent of vegetation through soils (pedosphere) down to unsaturated and saturated bedrock (Fig. 1), although the lower boundary, which marks the point where life no longer influences rock, remains undefined. The lower limit of the $\mathrm{CZ}$ has shifted deeper with the advent of modern microbiology which demonstrated that microorganisms can live in areas long thought to be uninhabitable (Gold, 1992). Even higher organisms, such as nematodes, have been recovered from fracture water $3.6 \mathrm{~km}$ below the surface in the deep gold mines of South Africa (Borgonie et al., 2011). Life is primarily limited in its penetration of the Earth's surface not by energy but by temperature, which increases rapidly with depth at an average rate of $25^{\circ} \mathrm{C} \mathrm{km}^{-1}$ (Bott, 1971). This suggests that, with an upper temperature limit of $130^{\circ} \mathrm{C}$ for bacteria (Kashefi, 2003), life could exist down to $5.2 \mathrm{~km}$ below the surface.

The Earth's outer shell is the "critical" arena where physical, chemical, and biological processes fundamental for sustaining both ecosystems and human societies occur and interact (Amundson et al., 2007; Brantley et al., 2007; Chorover et al., 2007; Lin, 2010). Biological and geological processes are unified via fluid transport, with water transferring energy and mass (Lin, 2010). Geology directly impacts life in the $\mathrm{CZ}$, as organisms cannot survive on unweathered bedrock; abiotic and biotic weathering processes are necessary to transform bedrock into a medium that can support life (Jin et al., 2010). The biological cycle is a combination of ecological and biogeochemical cycles involved in the

Published by Copernicus Publications on behalf of the European Geosciences Union. 


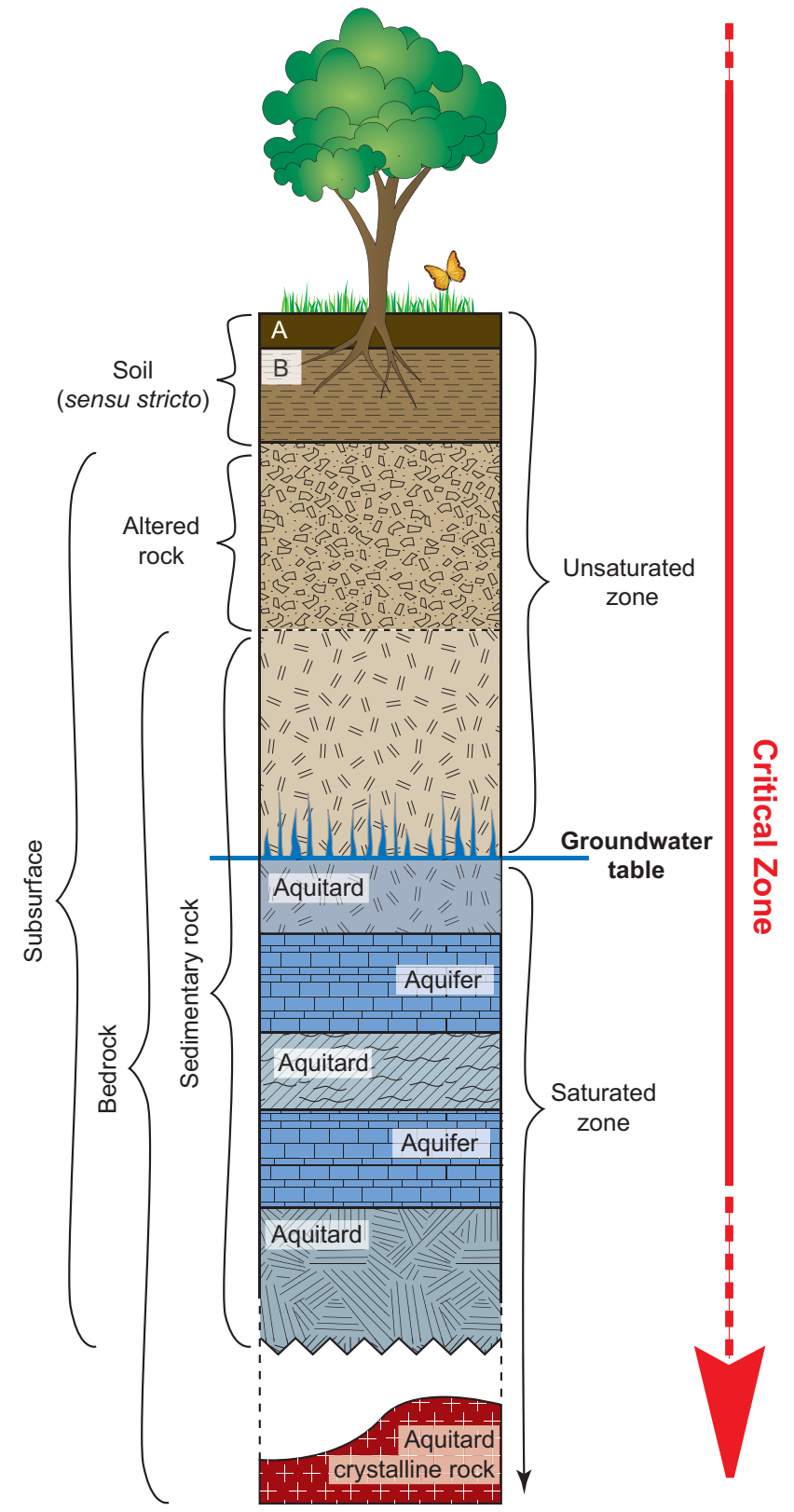

Fig. 1. The Earth's Critical Zone as exemplified for a sedimentary rock. The portion of the biosphere ranging from the outer extent of vegetation down through the lower limits of groundwater, including the soil, altered rock, the unsaturated zone, and the saturated zone (modified from Lin, 2010). A refers to the topsoil and B refers to the subsoil.

production and consumption of energy in an ecosystem (Lin, 2010). Microorganisms are central to this cycle as they can control food-web trophic interactions (the ecological cycle) and biogeochemical cycling of nutrients. Biotic and abiotic processes of the biogeochemical cycle are intimately linked to the ecological cycle because they determine the bioavailability of elements necessary for life, e.g. carbon, oxygen, and nitrogen. The ecological cycle consists of processes that support a food chain via the generation and consumption of biomass, with primary production carried out by producers, such as plants and autotrophic microbes. Fixed carbon moves up the food chain to consumers and ultimately, detritivores such as prokaryotes, fungi, and higher animals. In general, two types of ecological cycles occur within the CZ: those driven by surface energy inputs and those that depend on subsurface energy (Fig. 2).

CZ habitats are estimated to harbor the unseen majority of Earth's biomass with the total carbon in subsurface microorganisms likely equal to that in all terrestrial and marine plants (Whitman et al., 1998). The CZ microbial world includes prokaryotes (Bacteria and Archaea), eukaryotes (fungi, algae, and protozoa), and viruses. These microbes have developed an extraordinary diversity of metabolic potential and adapted to a wide range of habitats that vary in nutrient and water availability, depth, and temperature. Although the $\mathrm{CZ}$ is a unified biosphere, studies have traditionally divided it into five distinct geological zones: soils, the shallow subsurface, groundwater, caves, and the deep subsurface. Such zonation is likely irrelevant to the microbes who live there to whom, the defining features of a habitat are space, temperature, water, nutrients, and energy sources that can support microbial functional groups (Madsen, 2008).

In this review we examine what is currently known about microbiology within terrestrial CZ ecosystems. Physical and hydrological aspects of $\mathrm{CZ}$ processes have been described by Lin (2010) while others summarize the microbiology of specific CZ habitats, e.g. soils (Buckley and Schmidt, 2002), groundwater (Griebler and Lueders, 2009), and caves (Northup and Lavoie, 2001). This review instead synthesizes current knowledge regarding microbial biodiversity within specific terrestrial habitats and examines it within the larger context of the CZ. We intend to show that the sum of all microbial biodiversity within the linked ecosystems and zones of the $\mathrm{CZ}$ is greater than the individual components. Ultimately, we aim to facilitate a fuller understanding of complex Earth processes by stimulating microbiologists and ecologists to evaluate their data within the global $\mathrm{CZ}$ network.

\section{Impact of physical complexity on CZ microbiology}

CZ habitats vary in their physical, chemical, and biological heterogeneity with the most complex and productive regions occurring near the surface and less complex regions further below. Habitat complexity depends on weathering, where rocks are fractured, ground, dissolved, and bioturbated into transportable minerals (Brantley et al., 2007). Transport processes control the flux of water and nutrients through the $\mathrm{CZ}$, linking these regions and affecting microbial activity. While microorganisms live throughout the CZ (Table 1), their metabolic contribution depends on habitat complexity, the 


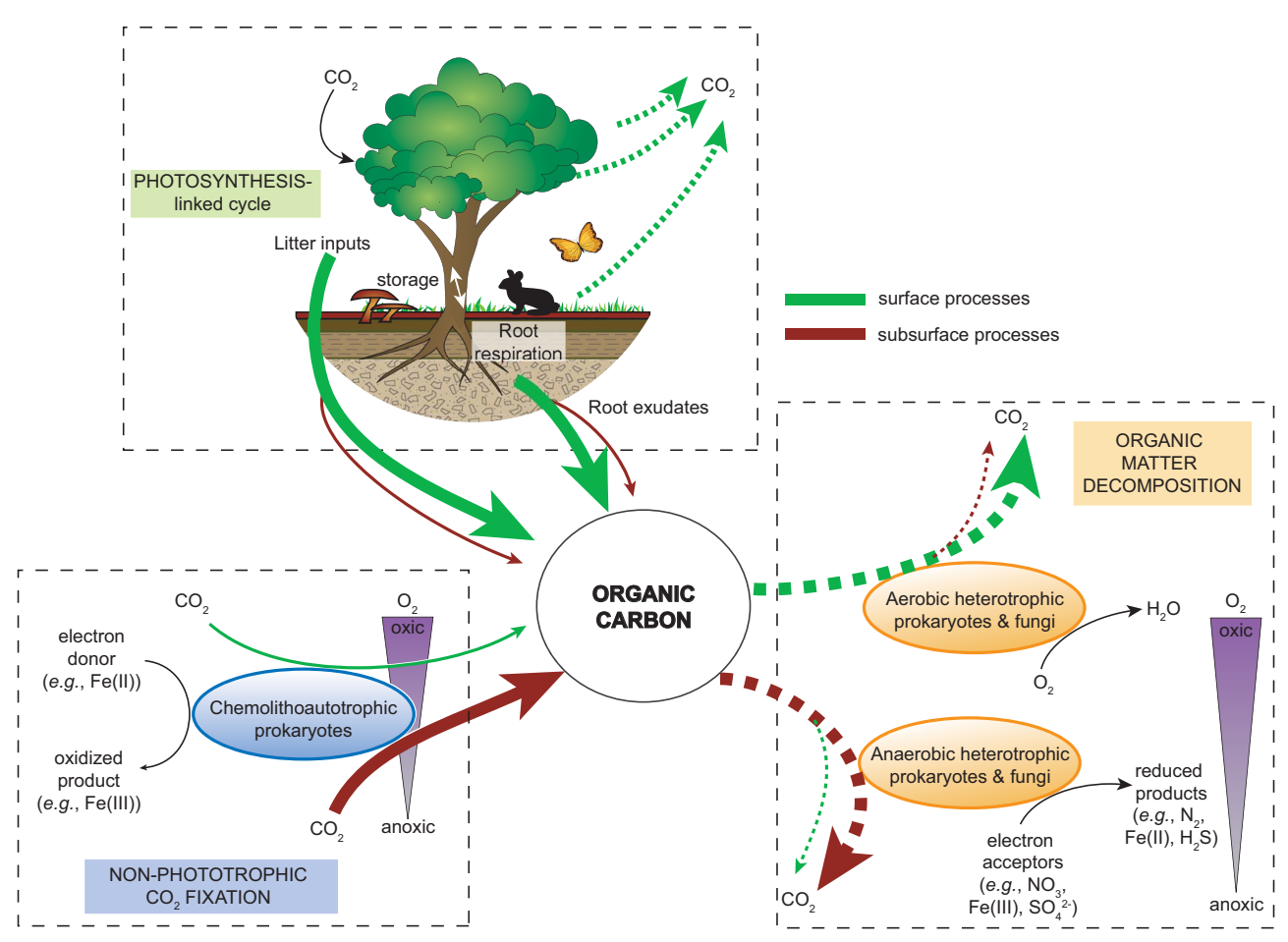

Fig. 2. The CZ biological cycle. Illustrated are the major pathways in which fixed carbon enters (solid arrows) and leaves (dashed arrows) the $\mathrm{CZ}$. The intensity of each pathway varies depending on location and is reflected by the size of the arrow. Arrows in green indicate the contribution of processes to surface habitats, whereas arrows in red reflect contributions to subsurface habitats.

spatial and temporal variability that influences pore space, water, oxygen, and nutrient availability for microbial life.

The three-dimensional weathered rock matrix of the $\mathrm{CZ}$ forms a variety of heterogeneous microhabitats for biota that differ in the amount and source of water input. Microhabitats range from $\mathrm{nm}$ to $\mathrm{cm}$ in scale and occur in pore spaces, fractures, or particle aggregates. Small pores (nm to $\mu \mathrm{m}$ ) are found within mineral particles, black carbon, or particle aggregates, and can be formed by abiotic processes, e.g. chemical weathering, fire, or aggregation, or via biological processes, e.g. bioturbation, root-soil interactions, or microbial activity (Jarvis, 2007; Chorover et al., 2007). In abiotic weathering, water enters the rock through vertical fractures, contacts rock walls, dissolves (trace) minerals, and oxidizes iron silicates. Plants exacerbate this weathering by extending roots into fractures to extract water, sometimes reaching over $20 \mathrm{~m}$ deep (Jackson et al., 1999). Such biological activity, in addition to bioturbation by soil fauna, root penetration and abiotic processes, such as shrinking and swelling of clay materials, rock fracturing, and preferential weathering (Jarvis, 2007; Chorover et al., 2007), creates large pore sizes (mm to $\mathrm{cm})$ in soils.

Water transports nutrients and gases through habitats via fractures and pore spaces, providing a constant source of elements to some CZ regions. Soils gain the majority of water from the atmosphere and interface with aquatic systems.
In the unsaturated zone, pore spaces are only partially filled with water, which moves primarily downward by the force of gravity. In the saturated zone, pore spaces are completely filled and water can also move horizontally in response to the hydraulic head. In deeper regions, water flow tends to decrease (Anderson et al., 2007) and can lead to nutrient limitation.

Microhabitat size and water availability can constrain CZ microbial distribution, as these organisms live within water films or on the surface of particles, pores, and fractures as microcolonies or biofilms, or in the interior of particle aggregates (Madigan et al., 2000; Young, 2008). In soils and the unsaturated zone, water availability limits both transport and the thickness of water films in pores (Young, 2008). Because water connects pores and controls the movement of organisms, dry areas increase niche separation and habitat diversity. Soil aggregate microhabitats are unique for prokaryotes because micron-scale gradients in water, nutrients, and oxygen can be found even within a small $3 \mathrm{~mm}$ sized aggregate (Madigan et al., 2000). Anoxic regions can form within the interior of soil aggregates due to variable gas diffusion and oxygen consumption near their surfaces. These micro-oxic or anoxic niches within aggregates within generally oxic soil habitats allow organisms to be active despite varying oxygen needs (Madigan et al., 2000) and can support very different microbial communities than the exterior 
Table 1. Examples of prokaryote abundance, phylogenetic diversity, and functional role in CZ habitats.

\begin{tabular}{|c|c|c|c|c|c|}
\hline Region & Habitat & $\begin{array}{l}\text { Prokaryote } \\
\text { abundance }\end{array}$ & Functional groups & $\begin{array}{l}\text { Phylogenetic groups detected } \\
\text { so far }\end{array}$ & References \\
\hline Pedosphere & Soils & $\begin{array}{l}10^{7} \text { to } \\
10^{10} \text { cells g soil }\end{array}$ & $\begin{array}{l}\text { Photoautotrophs (e.g. } \\
\mathrm{CO}_{2} \text {-fixing bacteria) } \\
\text { Heterotrophs (e.g. } \\
\text { aerobes and anaerobes, } \\
\text { nitrifiers, iron- and } \\
\text { sulfate-reducers, } \\
\mathrm{N}_{2} \text {-fixing bacteria, } \\
\text { denitrifiers, methylotrophs, } \\
\text { acetogens) } \\
\text { Chemolithoautotrophs (e.g. } \\
\text { ammonium oxidizers, } \\
\text { methanogens, } \\
\text { methanotrophs) }\end{array}$ & $\begin{array}{l}\text { Bacteria (Proteobacteria, } \\
\text { Acidobacteria, Actinobacteria, } \\
\text { Bacteroidetes, Chloroflexi, } \\
\text { Chlorobi, Cyanobacteria } \\
\text { Cytophagales, Deinococcus, } \\
\text { Ferribacter, Firmicutes, } \\
\text { Gemmatimonadetes, } \\
\text { Planctomycetes, Verrucomicrobia, } \\
\text { candidate divisions) } \\
\text { Archaea (Crenarchaeota, } \\
\text { Euryarchaeota) }\end{array}$ & $\begin{array}{l}\text { Torsvik et al. (2002); } \\
\text { Whitman et al. (1998); } \\
\text { Beloin et al. (1988); } \\
\text { Buckley and Schmidt (2002); } \\
\text { Miltner et al. (2004); } \\
\text { Brons and van Elsas (2008); } \\
\text { Kowalchuk and Stephen (2001); } \\
\text { Küsel and Drake (1995); } \\
\text { Küsel et al. (2002). }\end{array}$ \\
\hline $\begin{array}{l}\text { Unsaturated } \\
\text { bedrock }\end{array}$ & $\begin{array}{l}\text { Shallow } \\
\text { subsurface }\end{array}$ & $\begin{array}{l}10^{4} \text { to } \\
10^{8} \text { cells g }\end{array}$ & $\begin{array}{l}\text { Heterotrophs (e.g. aerobes } \\
\text { and anaerobes, nitrifying } \\
\text { bacteria, iron- and sulfate- } \\
\text { reducers, } \mathrm{N}_{2} \text {-fixing bacteria, } \\
\text { methane-oxidizers) } \\
\text { Chemolithoautotrophs (e.g. } \\
\text { Mn- and sulfur-oxidizers) }\end{array}$ & $\begin{array}{l}\text { Bacteria (Proteobacteria, } \\
\text { Acidobacteria, Actinobacteria, } \\
\text { Bacteroidetes, Chloroflexi, } \\
\text { Firmicutes, Planctomycetes, } \\
\text { Verrucomicrobia, candidate } \\
\text { divisions) }\end{array}$ & $\begin{array}{l}\text { Brockman and Murray (1997); } \\
\text { Kieft et al. (1993); } \\
\text { Balkwill and Ghiorse (1985); } \\
\text { Wilson et al. (1983); } \\
\text { Fliermans (1989); } \\
\text { Hazen et al. (1991); } \\
\text { Wang et al. (2008). }\end{array}$ \\
\hline \multirow[t]{3}{*}{$\begin{array}{l}\text { Saturated } \\
\text { bedrock }\end{array}$} & $\begin{array}{l}\text { Groundwater } \\
\text { ecosystems }\end{array}$ & $\begin{array}{l}10^{3} \text { to } \\
10^{8} \text { cells cm }{ }^{-3} \text { water } \\
>10^{10} \text { cells cm } \\
\text { porous sediment }\end{array}$ & $\begin{array}{l}\text { Heterotrophs (e.g. } \\
\text { oligotrophs, nitrifiers, } \\
\text { Mn-oxidizers, iron- and } \\
\text { sulfate-reducers) } \\
\text { Chemolithoautotrophs (e.g. } \\
\text { carbon-fixers, iron- and } \\
\text { sulfur-oxidizers) }\end{array}$ & $\begin{array}{l}\text { Bacteria (Proteobacteria, } \\
\text { Acidobacteria, Actinobacteria, } \\
\text { Bacteroidetes, Chloroflexi, } \\
\text { Firmicutes, Nitrospira, } \\
\text { Planctomycetes, Spirochaetes, } \\
\text { Verrucomicrobia, candidate } \\
\text { divisions) }\end{array}$ & $\begin{array}{l}\text { Ghiorse and Wilson (1988); } \\
\text { Madsen (2008); } \\
\text { Pedersen (2000); } \\
\text { Griebler and Lueders (2009); } \\
\text { Ellis et al. (1998); } \\
\text { Hirsch and } \\
\text { Rades-Rohkohl (1990); } \\
\text { Hazen et al. (1991); } \\
\text { Emerson and Moyer (1997); } \\
\text { Alfreider et al. (2009); } \\
\text { Akob et al. (2007, 2008). }\end{array}$ \\
\hline & Caves & $\begin{array}{l}10^{2} \text { to } \\
10^{8} \text { cells } \mathrm{cm}^{-3} \text { water } \\
\text { or sediment }\end{array}$ & $\begin{array}{l}\text { Heterotrophs (e.g. } \\
\text { oligotrophs, Mn-oxidizers, } \\
\text { nitrifiers, carbonate } \\
\text { precipitating bacteria, } \\
\text { sulfate-reducers) } \\
\text { Chemolithoautotrophs (e.g. } \\
\text { iron-, methane- and } \\
\text { sulfur-oxidizers) }\end{array}$ & $\begin{array}{l}\text { Bacteria (Proteobacteria, } \\
\text { Acidobacteria, Actinobacteria, } \\
\text { Bacteroidetes, Chloroflexi, } \\
\text { Cytophagales, Firmicutes, } \\
\text { Gemmatimonadetes, Nitrospira, } \\
\text { Planctomycetes, Verrucomicrobia) } \\
\text { Archaea (Crenarchaeota, } \\
\text { Euryarchaeota) }\end{array}$ & $\begin{array}{l}\text { Gounot (1994); } \\
\text { Farnleitner et al. (2005); } \\
\text { Rusterholtz and Mallory (1994); } \\
\text { Cunningham et al. (1995); } \\
\text { Northup and Lavoie (2001); } \\
\text { Northup et al. (2003); } \\
\text { Pašić et al. (2010); } \\
\text { Barton and Northup (2007); } \\
\text { Chen et al. (2009); } \\
\text { Engel et al. (2003, 2004). }\end{array}$ \\
\hline & $\begin{array}{l}\text { The deep } \\
\text { subsurface }\end{array}$ & $\begin{array}{l}10^{2} \text { to } 10^{8} \text { cells ml } \\
\text { groundwater } \\
>10^{7} \text { cells g dw } \\
\text { rock }^{-1}\end{array}$ & $\begin{array}{l}\text { Heterotrophs (e.g. } \\
\text { oligotrophs, thermophiles, } \\
\text { fermenters, } \mathrm{N}_{2} \text {-fixers, } \\
\text { nitrifiers, sulfate- and } \\
\text { iron- reducers) } \\
\text { Chemolithoautotrophs (e.g. } \\
\text { thermophiles methanogens, } \\
\text { acetogens, iron-, manganese-, } \\
\text { methane- and sulfur- } \\
\text { oxidizers) }\end{array}$ & $\begin{array}{l}\text { Bacteria (Proteobacteria, } \\
\text { Acidobacteria, Actinobacteria, } \\
\text { Bacteroidetes, Chlorobi, } \\
\text { Chloroflexi, Firmicutes, } \\
\text { Gemmatimonadetes, Nitrospira, } \\
\text { Planctomycetes, Verrucomicrobia, } \\
\text { candidate divisions) } \\
\text { Archaea (Crenarchaeota, } \\
\text { Euryarchaeota) }\end{array}$ & $\begin{array}{l}\text { Chapelle et al. (2002); } \\
\text { Pedersen (1993, 1997); } \\
\text { Madsen (2008); } \\
\text { O'Connell et al. (2003); } \\
\text { Rastogi et al. (2009); } \\
\text { Pfiffner et al. (2006); } \\
\text { Haldeman et al. (1993); } \\
\text { Chivian et al. (2008); } \\
\text { Lin et al. (2006). }\end{array}$ \\
\hline
\end{tabular}

(Drążkiewicz, 1994). The complex spatial and kinetic relationships between aerobic and anaerobic processes in soils are regulated by rainfall and drying patterns, leaching of dissolved organic carbon (DOC), and changes in oxygen consumption (Küsel and Drake, 1995). Acetate, a major fer- mentation product formed under anoxic conditions, e.g. in the centre of anoxic soil aggregates or within litter, can accumulate from soil organic matter (SOM) mineralization or diffuse to more oxic regions where it will be rapidly consumed by other microorganisms in the presence of terminal 
electron acceptors (TEAs), like $\mathrm{Fe}(\mathrm{III})$, nitrate, or $\mathrm{O}_{2}$ (Küsel et al., 2002; Fig. 2).

Biological complexity in the $\mathrm{CZ}$ correlates positively with pore size variability. Large pores in soils allow not only prokaryotes (Table 1) and micro-eukaryotes (Table 2), but also higher organisms (plant roots and macrofauna) to occur, although macrofauna and micro-eukaryotes inhabit larger pore spaces than prokaryotes (Young and Ritz, 2000). Prokaryotes use these smaller, inaccessible pores as refuges from grazing by higher trophic levels, e.g. Wright et al. (1993). Pore-space size also constrains the viability and activity of microbes in core samples; interconnected pore throats $>0.2 \mu \mathrm{m}$ diameter are required for sustained activity (Fredrickson et al., 1997). Unlike soils, the unsaturated and saturated bedrock of the deep biosphere has a large, solid surface-area-to-water-volume ratio and provides little space for water and microbes per unit volume of subsurface (Pedersen, 2000). Communities in the deep subsurface include prokaryotes (Table 1) and micro-eukaryotes (Table 2) with a only single report of higher fauna to date (Borgonie et al., 2011). These organisms can live only in pores or fractures and are generally cut-off from surface energy inputs.

In addition to water and space, microorganisms also require carbon, nitrogen, electron donors (carbon or inorganic compounds), TEAs (oxygen, nitrate, sulfate, Fe(III), etc.), and trace minerals. In aerobic and anaerobic metabolisms, organisms generate energy (ATP) via the coupled oxidation of an electron donor to the reduction of a TEA; with aerobes respiring oxygen and anaerobes reducing alternative TEA, e.g. nitrate, sulfur species, and metals (e.g. Fe(III), $\mathrm{Mn}(\mathrm{IV})$, and some heavy metals) (Fig. 2). The availability of these resources in the $\mathrm{CZ}$ depends on nutrient source proximity and competition with other organisms. Competition for scarce nitrogen, iron, and phosphorus between microbes selects for extremely nutrient efficient populations (Madigan et al., 2000). Prokaryotes have evolved traits to overcome nutrient limitations, such as chemolithoautotrophy, nitrogen fixation or scavenging iron and other metals with siderophores. In addition, two types of microbial populations have been identified that differ in their carbon substrate usage: r-strategists which feed on fresh organic matter $(\mathrm{OM})$, and k-strategists which utilize remaining polymerized substrates such as buried carbon (summarized in Fontaine et al., 2003).

The input source of carbon and oxygen into a CZ habitat depends on its distance from the surface. Soils have the highest organic carbon and oxygen inputs due to rhizodeposition from higher plants or macrofauna and proximity to the atmosphere (as summarized in Hinsinger et al., 2009; Fig. 2). Deposited carbon fuels soil microbial communities of heterotrophic fungi and bacteria that respire the $\mathrm{OM}$ of fresh plant litter, dead plant roots and root exudates (Fig. 2). OM decomposition rates are affected by the source as well as by community structure as different microbial communities prefer different carbon substrates. Complex microbial commu- nities and processes thrive in soil ecosystems due to the high OM input and the availability of high-energy electron acceptors, e.g. oxygen and nitrate (Table 1). Variability in carbon and oxygen input and consumption can lead, as in soil aggregates (see above), to the formation of carbon-depleted and anoxic or micro-oxic niches within habitats that support the growth of oligotrophic or autotrophic organisms (Table 1, Fig. 2). Although non-photoautotrophic microbial $\mathrm{CO}_{2}$ fixation (Fig. 2) is only a minor input to the bulk soil $(0.05 \%$ of soil organic carbon), it can be important in soil microenvironments (Miltner et al., 2004, 2005).

In general, organisms in deeper $\mathrm{CZ}$ regions with little oxygen and OM input must be well adapted to life under anoxic and oligotrophic conditions. Oligotrophic conditions vary in the subsurface, with some habitats experiencing little to no input of fixed carbon from the surface for long periods of time. Such sporadic input causes microbial communities to evolve different survival strategies than their counterparts, which experience low but constant nutrient supply in shallower CZ ecosystems. Oligotrophic conditions can form due to limited transport of OM from the surface, as the depth that photosynthesis-derived $\mathrm{C}$ travels in the $\mathrm{CZ}$ depends on plant rooting depth, vertical water flow, and burial. Therefore, microbes in deep regions of the $\mathrm{CZ}$ depend on either old OM, e.g. deposits in rocks or sediments (Krumholz, 2000), or sources of inorganic electron donors and inorganic carbon for chemolithoautotrophic metabolism (Fig. 2). Primary production by chemolithoautotrophic Bacteria and Archaea can anchor a food chain that is independent from the surface (Fig. 2). For example, in deep biosphere basalt and granitic systems, acetogenic and methanogenic primary producers (Bacteria and Archaea, respectively), utilize geologically produced $\mathrm{H}_{2}$ and $\mathrm{CO}_{2}$ for the production of acetate and methane, respectively (Pedersen, 1997; Chapelle et al., 2002; Chivian et al., 2008; Lin et al., 2006; Fig. 2). Obligately anaerobic, $\mathrm{CO}_{2}$-reducing acetogens and methanogens use the Wood-Ljungdahl (acetyl-CoA) pathway not only as a terminal electron accepting, energy-conserving process, but also as a mechanism for cell carbon synthesis from $\mathrm{CO}_{2}$ (Drake et al., 2006). The methane and acetate produced then supports the growth of acetoclastic methanogens, sulfate- (SRB), and iron-reducing bacteria (FeRB). As secondary consumers synthesize biomass, they in turn provide a source of carbon and energy for anaerobic heterotrophs (Fig. 2). Lithoautotrophy in the deep biosphere is also driven by other energy sources. While organisms that do not require $\mathrm{H}_{2}$ or photosynthesisderived organic carbon are rare, they may provide sufficient energy for microbial primary production (Stevens, 1997; Amend and Teske, 2005) through the disproportionation of sulfur $\left(\mathrm{S}^{0}\right)$, sulfite $\left(\mathrm{SO}_{3}^{2-}\right)$ or thiosulfate $\left(\mathrm{S}_{2} \mathrm{O}_{3}^{2-}\right)$, or the oxidation of $\mathrm{Fe}(\mathrm{II}), \mathrm{S}^{0}$, or $\mathrm{S}_{2} \mathrm{O}_{3}^{2-}$ with reduction of nitrate or $\mathrm{Fe}(\mathrm{III})$. Alternative energy sources, e.g. metals, sulfur, etc., that have accumulated from rock weathering help sustain life in such deep anoxic habitats. This is similar to the conditions of early Earth, where respiratory processes included sulfur or 
Table 2. Micro-eukaryote abundance and functional or phylogenetic diversity in CZ habitats.

\begin{tabular}{|c|c|c|c|c|}
\hline Region & Habitat & Abundance & Functional or phylogenetic groups & References \\
\hline \multirow[t]{2}{*}{ Pedosphere } & \multirow[t]{2}{*}{ Soils } & $\begin{array}{l}10^{1} \text { to } \\
10^{7} \text { cells g dw soil }\end{array}$ & $\begin{array}{l}\text { Protozoa (flagellates, ciliates, } \\
\text { naked and testate amoeba) }\end{array}$ & $\begin{array}{l}\text { Beloin et al. (1988); } \\
\text { van Schöll et al. (2008); } \\
\text { Brad et al. (2008); } \\
\text { Strauss and Dodds (1997); } \\
\text { Lara et al. (2007); } \\
\text { Ekelund et al. (2001); } \\
\text { Adl and Gupta (2006); } \\
\text { Robinson et al. (2002). }\end{array}$ \\
\hline & & $\begin{array}{l}>10^{3} \text { cells g } \\
\text { sediment }^{-1}\end{array}$ & $\begin{array}{l}\text { Fungi (Basidiomycota, Ascomycota, } \\
\text { Chytridomycota, Zygomycota, } \\
\text { Glomeromycota) }\end{array}$ & $\begin{array}{l}\text { Brad et al. (2008); } \\
\text { Malloch et al. (1980); } \\
\text { Kurakov et al. (2008). }\end{array}$ \\
\hline $\begin{array}{l}\text { Unsaturated } \\
\text { bedrock }\end{array}$ & $\begin{array}{l}\text { Shallow } \\
\text { subsurface }\end{array}$ & $\begin{array}{l}>10^{3} \text { cells g dw soil }^{-1} \\
\text { or sediment }^{-1} \\
>18 \text { cells } \mathrm{g} \mathrm{dw} \text { sediment }\end{array}$ & $\begin{array}{l}\text { Protozoa (flagellates, amoeba) } \\
\text { Fungi (yeasts) }\end{array}$ & $\begin{array}{l}\text { Fliermans (1989); } \\
\text { Ekelund et al. (2001). }\end{array}$ \\
\hline \multirow[t]{5}{*}{$\begin{array}{l}\text { Saturated } \\
\text { bedrock }\end{array}$} & \multirow[t]{2}{*}{$\begin{array}{l}\text { Groundwater } \\
\text { ecosystems }\end{array}$} & $\begin{array}{l}<10^{0} \text { to } 10^{8} \text { cells g dw } \\
\text { aquifer material } \\
<3 \text { flagellates } \mathrm{ml}^{-1}\end{array}$ & $\begin{array}{l}\text { Protozoa (flagellates, ciliates, naked } \\
\text { amoeba, heliozoans) }\end{array}$ & $\begin{array}{l}\text { Novarino et al. (1997); } \\
\text { Ellis et al. (1998); } \\
\text { Novarino et al. (1994); } \\
\text { Ekelund et al. (2001); } \\
\text { Loquay et al. (2009). }\end{array}$ \\
\hline & & $\begin{array}{l}>652 \text { cells cm rock } \\
>91 \text { cells } \mathrm{ml} \mathrm{water}^{-1}\end{array}$ & $\begin{array}{l}\text { Fungi (unclassified hyphomycetes, } \\
\text { Ascomycota, Zygomycota, } \\
\text { Oomycetes) }\end{array}$ & $\begin{array}{l}\text { Krauss et al. (2003, 2005); } \\
\text { Ellis et al. (1998); } \\
\text { Göttlich et al. (2002); } \\
\text { Solé et al. (2008); } \\
\text { Kuehn and Koehn (1988). }\end{array}$ \\
\hline & \multirow[t]{2}{*}{ Caves } & $\begin{array}{l}<10^{0} \text { flagellates } \mathrm{ml}^{-1} \text { in } \\
\text { free water } \\
2 \times 10^{1} \text { flagellates } \mathrm{ml}^{-1} \\
\text { pore water }\end{array}$ & $\begin{array}{l}\text { Protozoa (flagellates, ciliates, naked } \\
\text { amoeba, heliozoans) }\end{array}$ & Loquay et al. (2009). \\
\hline & & $>10^{5}$ cells g ${ }^{-1}$ & $\begin{array}{l}\text { Fungi (Ascomycota, Zygomycota, } \\
\text { Rhizopus) }\end{array}$ & $\begin{array}{l}\text { Cunningham et al. (1995); } \\
\text { Northup and Lavoie (2001); } \\
\text { Elhottová et al. (2006). }\end{array}$ \\
\hline & $\begin{array}{l}\text { The deep } \\
\text { subsurface }\end{array}$ & $\begin{array}{l}0.01 \text { to } \\
1 \text { cells ml groundwater }\end{array}$ & $\begin{array}{l}\text { Fungi (yeasts (Basidiomycota), } \\
\text { molds) }\end{array}$ & Ekendahl et al. (2003). \\
\hline
\end{tabular}

iron reduction (Madigan et al., 2000; Pace, 1997). However, oxic environments can also exist in the subsurface where radioactivity causes radiolysis of water (Onstott et al., 2003).

Groundwater and cave ecosystems require a special note regarding how physical complexity affects biology. Both are distinguished from soil and subsurface habitats by having no photosynthesis and for the most part, lack inputs of easily available carbon (Griebler and Lueders, 2009). While groundwater ecosystems in shallow and deep aquifers often share space and nutrient characteristics with the shallow and deep subsurface, water flow through an aquifer can enhance microbial activity by replenishing nutrients. Within aquifers, prokaryotes primarily live attached to surfaces, such as sediment particles, rock surfaces, and detritus (Griebler and
Lueders, 2009). Unlike groundwater ecosystems, caves are gigantic pores within the $\mathrm{CZ}$ characterized by different types of rock and are formed by geological processes such as chemical dissolution, erosion by water, and activity of microorganisms (Northup and Lavoie, 2001). Depending on their connectivity to the surface and water sources, caves often are not oxygen or water limited. The large size of a cave also provides many different microhabitats for microbes as well as space for higher organisms. Microbes can be found in cave water or sediments and on rock surfaces as biofilms. Although caves are oligotrophic, conditions can be ideal for life because they have very stable physical parameters, e.g. temperature and humidity (Northup and Lavoie, 2001). 


\section{Microbial ecology in the $\mathrm{CZ}$}

CZ habitats are estimated to harbor an unseen majority of Earth's biomass with the total carbon in subsurface organisms likely equal to that in all terrestrial and marine plants (Whitman et al., 1998). The prokaryotes (Bacteria and Archaea) and eukaryotes (fungi, algae, and protozoa) that thrive in the $\mathrm{CZ}$ fall into numerous functional groups that are well suited to their habitat. Relevant functional groups in the $\mathrm{CZ}$ include the aforementioned aerobic and anaerobic heterotrophs and chemolithoautotrophs, all of which influence carbon, nitrogen, sulfur, and metal cycling. The distribution, biomass, and activity of these groups depend on the availability of appropriate nutrients and energy sources in their habitat.

\subsection{Prokaryote communities}

Understanding the role of prokaryotes in the environment has long posed a challenge to scientists, as they are invisible to the naked eye. Historically, the main approach to studying microbes was cultivation combined with identification based on morphology or physiology. However, microscopic counts of bacteria are always much higher than what is recovered by cultivation methods ( $<1 \%$ of total bacteria, Amann et al., 1995). The advent of cultivation-independent techniques targeting small subunit ribosomal RNA molecules (SSU rRNA) has since revealed a huge phylogenetic diversity (Hugenholtz et al., 1998). This was a huge step forward for microbiology, but did little to expand our knowledge of the functional role of uncultured organisms.

The fact that only $<1 \%$ of all prokaryotes are culturable likely results from time-consuming cultivation methods which traditionally use nutrient-rich media, which varies greatly from environmental conditions. Such media is not ideal for obtaining organisms in isolation that have specific growth requirements (e.g. specific nutrients, $\mathrm{pH}$ conditions, incubation temperatures, or oxygen), require interactions with other organisms (Vartoukian et al., 2010), or have different growth strategies such as sporadic growth (rapid growth when conditions are ideal, followed by a senescent stage), slow growth rates, or periods of dormancy (Madsen, 2008). Different growth strategies are important prokaryote adaptations to high habitat variability; most subsurface microorganisms live in conditions of extreme energy limitation, with long generation times. Prokaryotes that survive with little nutrients in ice, permafrost, the desert-like seafloor, or deep subsurface groundwater has profoundly altered our perspective on the limits of living organisms and their need for energy (Price and Sowers, 2004; Chivian et al., 2008; Lin et al., 2006). These microorganisms maintain complex functions at an energy flux that barely allows cell growth over tens to thousands of years. The energy available might only be sufficient to maintain cell processes exclusive of biomass production (maintenance energy) or allow macromolecular damage repairs (survival energy). The lowest metabolic rate of immobile, likely dormant communities with extremely weak metabolisms is clearly different from that of mobile communities with greater nutrient access (Price and Sowers, 2004). Metabolic rates per cell, corresponding to growth, maintenance, and survival, can differ over six orders of magnitude. Classical cultivation techniques are therefore somewhat inappropriate to understand microbial life under extremely energy-depleted conditions. With this perspective, numerous methods were developed that target "unculturable" prokaryotes (Vartoukian et al., 2010), so that their role in biogeochemical cycles can be identified.

Examples of the vast phylogenetic diversity and functional roles of prokaryote communities in the $\mathrm{CZ}$ from cultivationdependent and - independent studies are summarized in Table 1. A common theme is the detection of aerobic heterotrophs. This is likely due to both the importance of this functional group to $\mathrm{CZ}$ processes and to their ease of cultivation. However, cultivation-independent methods demonstrate that these organisms are but a small fraction of the total community in oligotrophic habitats, and new cultivationdependent methods are expanding our knowledge about other important functional groups. For example, the anaerobic oxidation of ammonium with nitrite (Anammox), previously believed to be impossible, is now recognized as an important process in the marine nitrogen cycle and may be responsible for up to $50 \%$ of the global removal of fixed nitrogen from the oceans (Dalsgaard et al., 2005). Prokaryotes were recently shown to have a fourth pathway of oxygen production that might have considerable geochemical and evolutionary importance. An enrichment culture was shown to couple anaerobic oxidation of methane with the reduction of nitrite to dinitrogen (Ettwig et al., 2010). An important step in finding such new processes seems to be the postulation of an ecological niche based on thermodynamic considerations, in which various electron donors and acceptors are combined to calculate possible combinations. Other sources of inspiration for interesting new microbial processes can be ecological field data such as spatial or temporal profiles. As researchers have closer look into the $\mathrm{CZ}$ using a polyphasic approach, new discoveries should continue over the next several years.

Prokaryote abundances in the $\mathrm{CZ}$ tend to be highest in soils $\left(>10^{10}\right.$ cells $g$ soil $^{-1}$, Table 1$)$ and decrease with depth. Additionally, it has been estimated that a single gram of soil contains at least 4000 different species (Buckley and Schmidt, 2002). Soil prokaryotes also have a high metabolic diversity; most functional groups are found in numerous phylogenetic groups (Table 1). Many of these are important in nitrogen and carbon cycling with aerobic or anaerobic metabolisms. Nitrogen-cycling bacteria in soils, e.g. $\mathrm{N}_{2}$-fixers, denitrifiers, and nitrifiers, play a vital role in nitrogen availability, thereby exerting some control on plant primary production (Buckley and Schmidt, 2002; Wall et al., 2010). Methanogens, methylotrophs, heterotrophs, acetogens, and $\mathrm{CO}_{2}$-fixing bacteria 
contribute to the carbon cycle and fluxes of $\mathrm{C}$ in and out of soil (Buckley and Schmidt, 2002; Küsel and Drake, 1994, 1995; Fig. 2).

In subsurface (shallow and deep) and groundwater ecosystems, prokaryotes range in abundance from $10^{2}$ to $10^{8}$ cells g rock $^{-1}$, sediment ${ }^{-1}$, or $\mathrm{ml}$ groundwater $^{-1}$ (Table 1). These communities include diverse phylogenetic lineages that have high metabolic capacities, although fewer functional groups were detected than in soils (Table 1). Surprisingly, prokaryote abundance in the deep subsurface is similar to shallower groundwater ecosystems. From 50$4200 \mathrm{~m}$ below the surface, prokaryotes in deep groundwater, sediments, and rock (granite, limestone, and basalts) range from $10^{2}$ to $10^{8}$ cells ml groundwater ${ }^{-1}$ to $10^{2}$ to $10^{8}$ cells g dw sediment ${ }^{-1}$ or rock $^{-1}$ and include aerobes and anaerobes (Table 1). Studies have shown that members of many Bacteria phyla and a few novel lineages live in groundwater ecosystems (Table 1), with communities in pristine groundwater systems differing from surface communities (Griebler and Lueders, 2009). In uranium-contaminated subsurface sediments, microbial populations are often active, but metabolic activity is difficult to measure without the addition of carbon substrates to fuel anaerobic growth (Akob et al., 2007, 2008).

Organisms cultivated from the deep display a wide array of metabolic potential, including oligotrophic heterotrophs, chemolithoautotrophs, SRB and FeRB (Table 1). While food-webs in deep continental basaltic and granitic aquifers are primarily driven by chemolithoautotrophy (Pedersen, 1997; Chapelle et al., 2002; Amend and Teske, 2005), in other deep subsurface environments, heterotrophic SRB, living at geological interfaces between sandstone and clays, gain energy and carbon from surrounding shale (Krumholz et al., 1997). SRB located in highly porous sandstones appear to be dependent on old carbon in shales diffusing to their microhabitat. There is also evidence that novel Archaea and Bacteria exist in deep biosphere habitats (Takai et al., 2001; Lin et al., 2006; Chivian et al., 2008), such as Desulforudis audaxviator the dominant organism in fracture water collected from a $2.8 \mathrm{~km}$ depth in a South African gold mine. It is unique as its genome contains all the genetic machinery needed to exist in an anoxic and nutrient poor habitat, e.g. genes for sulfate reduction, chemolithoautotrophy, and $\mathrm{N}_{2}$-fixation (Chivian et al., 2008).

Caves harbor diverse microbial and macrofaunal communities and here we will describe the microbial communities in a few well-studied cave systems that differ in their mechanism of formation. Microbial food-webs in the Movile Cave in Romania and the Lower Kane Cave in Wyoming, which formed via sulfuric acid dissolution (Sarbu et al., 1996; Engel et al., 2003), rely entirely on chemolithoautotrophy via methane and sulfide oxidation (Chen et al., 2009). In these caves, microbial mats include sulfur-oxidizing members of the Beta- (Thiobacillus), Gamma- and Epsilonproteobacteria (Sarbu et al., 1996; Engel et al., 2003; Chen et al.,
2009), which produce sulfuric acid that weathers the carbonate bedrock of the caves (Sarbu et al., 1996). In karstic caves, calcium carbonate structures are ubiquitous and microorganisms (Bacteria and fungi) can participate in carbonate mineral formation (Northup and Lavoie, 2001; Rusznyák et al., 2011), by precipitating carbonate using metabolic pathways typically associated with photosynthesis and nitrogen and sulfur cycling (Castanier et al., 1999).

While prokaryotes in CZ habitats vary in abundance, depending on depth, a common theme among them is high phylogenetic diversity, although many phyla within the domain Bacteria are ubiquitous in the CZ. Our list is far from complete and research is constantly expanding our knowledge of microbial ecology in the CZ. While cultivationdependent techniques have revealed the metabolism of some $\mathrm{CZ}$ prokaryotes, the function of the majority of $\mathrm{CZ}$ microbes remains to be discovered. New techniques and efforts to cultivate previously unculturable prokaryotes should reveal a variety of new roles for prokaryotes in the $\mathrm{CZ}$.

\subsection{Fungal communities}

Fungi, heterotrophic organisms that are found in all regions of the $\mathrm{CZ}$, are identified by morphological characteristics, physiology, or genetics. They have remarkably diverse physiologies, which are summarized briefly below, but for a detailed review of the potential roles of fungi in geomicrobiology we refer readers to Gadd and Raven's (2010) excellent review. Fungi in the $\mathrm{CZ}$ are known best in soil habitats, where they occur at up to $10^{3}$ cells g soil $^{-1}$ (Table 2) and include symbiotic mycorrhizal fungi and free-living decomposers. Mycorrhizal fungi live in association with plants as either intracellular (arbuscular mycorrhizal fungi) or extracellular symbionts (ectomycorrhizal fungi) (Malloch et al., 1980). These organisms directly affect nutrient cycling and primary productivity in soils by decomposing SOM, taking up inorganic minerals, producing plant growth substances, and improving plant nutrient absorption. Ectomycorrhizal fungi contribute to mineral weathering in soils and shallow rocks, accounting for $>50 \%$ of total weathering via hyphae tunneling or the excretion of organic acids (van Schöll et al., 2008), thereby increasing both inorganic mineral availability to other organisms and habitat availability.

Fungi have been detected at low abundance in the shallow subsurface and groundwater (Table 2); with most reports based on microscopic observations of spores or fungal hyphae so little is known about identities or functional roles in the ecosystem (Krauss et al., 2003). However, the abundance of fungi was typically higher on rock material than in the interstitial water of an aquifer (Ellis et al., 1998; Table 2). Many groups detected in groundwater were related to fungi that are well adapted to oligotrophic conditions (Göttlich et al., 2002). While it is likely that these organisms are heterotrophs, feeding on prokaryote biomass and decaying $\mathrm{OM}$, their exact functional role remains unknown. In 
cave ecosystems, fungi can contribute to calcium carbonate crystallization (Northup and Lavoie, 2001), thereby playing a unique role in their habitat by helping form characteristic speleothems in caves.

In the deep subsurface biosphere, 200 to $450 \mathrm{~m}$ below sea level, isolated fungi were found to be at the lowest abundance (Ekendahl et al., 2003) of all CZ habitats. Of the 5 yeast, 3 yeast-like, and 17 mold strains isolated, the yeasts appeared to be most well adapted to subsurface conditions with small size and growth over a wide $\mathrm{pH}$ and temperature range (Ekendahl et al., 2003). The yeasts' small size is likely an adaption to living in small pore spaces or rock fractures. The lower abundances of these micro-eukaryotes in the deep subsurface compared to prokaryotes, suggest that these fungi are either limited in space or nutrients or are unable to cope with anoxia. However, a recent study showed that up to $2 \%$ of fungi in soils are facultative anaerobes (Kurakov et al., 2008), suggesting that anoxic conditions may not absolutely limit fungal activity. Although this is a small percentage of the total population, because fungi are such important drivers of weathering, they may be playing an important role in weathering even within anoxic microzones or habitats.

\subsection{Protozoa in the $\mathrm{CZ}$}

Protozoa have been found in the upper CZ habitats and their abundance decreases with depth (Table 2). Traditionally, protozoa were studied using morphological observations; however, the diversity of this group has expanded with the recent application of molecular techniques (Finlay and Fenchel, 2001). In soils, the many types of protozoa collectively range in abundance from $10^{1}$ to $10^{7}$ cells g dw soil ${ }^{-1}$ (Table 2). They affect nutrient cycling by consuming bacteria, excreting ingested nutrients directly into the soil system (Griffiths, 1994), and influencing plant root growth (Bonkowski, 2004). In the shallow subsurface, flagellates and amoeba have been observed at $>10^{3}$ cells g dw soil ${ }^{-1}$ or sediment $^{-1}$ (Table 2 ). In groundwater habitats, protozoa are key predators in the microbial loop, feeding on bacteria and other protozoa, or act as detritivores (Novarino et al., 1997). Although their abundance is estimated to be low in pristine aquifers, it can be as high as $10^{8}$ cells g dw aquifer material ${ }^{-1}$ in contaminated environments (Table 2). Cultivation-independent methods suggest that protozoa are also present in the deep subsurface (Pfiffner et al., 2006), although additional work is needed to confirm this observation. Although a breadth of knowledge details their role in soils, research documenting the community structure and functional role of protozoa in other $\mathrm{CZ}$ habitats remains limited. Protozoan community structure in soils appears to depend on habitat space and energy requirements (Finlay and Fenchel, 2001); we hypothesize that similar constraints influence communities elsewhere in the CZ.

\section{Implications for future studies}

Work on microbes within distinct $\mathrm{CZ}$ regions has clearly demonstrated that they are found everywhere, can mediate a wide range of biogeochemical processes, and have distributions impacted by the physical nature of their habitat. Future work should attempt to understand how microbial populations influence the links between different regions of the $\mathrm{CZ}$ and weathering processes. It is important to evaluate how microbial activity impacts fluxes of carbon, particulates, and reactive gases between and within $\mathrm{CZ}$ regions. Microbes, especially those involved in carbon and nitrogen cycling, are potential sources or sinks of carbon and gases. The effect of these microbial consumers and producers along with the transport of biomass on the flux of particulate OM needs to be evaluated in all regions of the CZ. It is unknown whether microbial biomass is transported within the $\mathrm{CZ}$ solely by abiotic means, such as water flow, or via biotic strategies. Bacteria can utilize fungal hyphae "highways" to move through soils (Kohlmeier et al., 2005) or disperse via zooplankton in aquatic habitats (Grossart et al., 2010), but whether these strategies are used elsewhere in the $\mathrm{CZ}$ is unknown. $\mathrm{Fu}-$ ture work should also determine if microbial activity reduces transport, such as when microbes reduce or impede water flow via biofilm or secondary mineral formation. In order to study this, it is necessary to determine the total biodiversity of surface-associated microbial communities in aquifers not just that of the more easily obtained, free-living, organisms.

Understanding weathering processes is an important goal of CZ science. Research on microbial contributions to weathering has focused primarily on the role of soil microbiota and fungal-associated weathering processes mediated especially by ectomycorrhizal fungi, (e.g. Balogh-Brunstad and Keller, 2010; Holmström et al., 2010; Schmalenberger et al., 2010; Bridge et al., 2010). These studies and others, (e.g. Balogh-Brunstad et al., 2008), provide valuable insight into fungal weathering processes in the rhizosphere and the upper 1-2 $\mathrm{m}$ of the CZ. As fungi also inhabit deeper regions of the $\mathrm{CZ}$, it is necessary to assess the role of these organisms elsewhere, especially the deep subsurface ( $>200 \mathrm{~m}$ ). For lithoautotrophic microorganisms, weathering provides solutes for primary production and is crucial for sustaining life, therefore, it is important to evaluate whether they can contribute directly to weathering by modifying their own microenvironment.

Providing a link between observed microbial populations and geochemical processes is a key goal of microbial ecology and is especially important for understanding complex $\mathrm{CZ}$ processes. While molecular-based approaches and new cultivation techniques have advanced knowledge of microbial biodiversity and allowed the study of prokaryotes in isolation, new "omics" technologies now provide microbial ecologists with even better tools to understand in situ microbial communities. Genomic and metagenomic techniques can provide information regarding the genetic potential of 
microbes (Cardenas and Tiedje, 2008), whereas proteomics can convey functional information about microbial activity (Dill et al., 2010). For example, the ability to link genetic potential to geochemistry allowed for the discovery of a potentially unculturable organism (Desulforudis audaxviator) that lives in complete isolation from surface nutrient inputs (Chivian et al., 2008). Differentiating between populations present in an environmental sample from those that are actively catalyzing observed geochemical processes has long been a difficult task. However, DNA- and RNA-stable isotope probing methods, which rely on the addition of a labeled substrate that is incorporating into cell biomass, can directly link activity to phylogeny (Radajewski et al., 2002; Dumont and Murrell, 2005; Manefield et al., 2002).

The potential for genomics to drive polyphasic research was recently revealed in the marine literature, where the genomic sequence of a hyperthermophilic Archaea indicated the presence of gene clusters that were implicated in formate oxidation coupled to $\mathrm{H}_{2}$ production (Kim et al., 2010), a metabolism that should be thermodynamically unfavorable. By using genomic data as a guide, experiments revealed that a simple, previously unknown anaerobic respiration process could support growth of microorganisms. This demonstrates how "omics" technologies can be used to target prokaryote functional groups and reveal new metabolic pathways for biogeochemical nutrient cycling. Currently, the most important challenge faced by $\mathrm{CZ}$ researchers is to determine the true potential and functionality of subsurface populations. Meeting this challenge will require both polyphasic and interdisciplinary approaches to truly understand the complexities of $\mathrm{CZ}$ microbiology. Microbiology cannot quantify the impact of microorganisms on $\mathrm{CZ}$ processes in isolation; only through collaboration with geologists and geochemists can we shed light on the mysteries of the $\mathrm{CZ}$.

Acknowledgements. This study is a part of the AquaDiv@Jena research project funded by the federal state of Thuringia's ProExcellence Initiative. The authors thank Anna Rusznyák, Ute Risse-Buhl, Peter Bouwma, Jonas Kley, Nina Kukowski, Beate Michalzik, Kai Uwe Totsche, and Susan Trumbore for helpful discussions.

Edited by: J. Middelburg

\section{References}

Adl, M. S. and Gupta, V. S.: Protists in soil ecology and forest nutrient cycling, Can. J. Forest Res., 36, 1805-1817, 2006.

Akob, D. M., Mills, H. J., and Kostka, J. E.: Metabolically active microbial communities in uranium-contaminated subsurface sediments, FEMS Microbiol. Ecol., 59, 95-107, 2007.

Akob, D. M., Mills, H. J., Gihring, T. M., Kerkhof, L., Stucki, J. W., Anastacio, A. S., Chin, K.-J., Küsel, K., Palumbo, A. V., Watson, D. B., and Kostka, J. E.: Functional diversity and electron donor dependence of microbial populations capable of $\mathrm{U}(\mathrm{VI})$ reduction in radionuclide-contaminated subsurface sediments, Appl. Environ. Microb., 74, 3159-3170, 2008.

Alfreider, A., Vogt, C., Geiger-Kaiser, M., and Psenner, R.: Distribution and diversity of autotrophic bacteria in groundwater systems based on the analysis of RubisCO genotypes, Syst. Appl. Microbiol., 32, 140-150, 2009.

Amann, R., Ludwig, W., and Schleifer, K.-H.: Phylogenetic identification and in situ detection of individual microbial cells without cultivation, Microbiol. Rev., 59, 143-169, 1995.

Amend, J. P. and Teske, A.: Expanding frontiers in deep subsurface microbiology, Palaeogeogr. Palaeocl., 219, 131-155, 2005.

Amundson, R., Richter, D. D., Humphreys, G. S., Jobbagy, E. G., and Gaillardet, J.: Coupling between biota and earth materials in the Critical Zone, Elements, 3, 327-332, 2007.

Anderson, S. P., von Blanckenburg, F., and White, A. F.: Physical and chemical controls on the Critical Zone, Elements, 3, 315319, 2007.

Balkwill, D. L. and Ghiorse, W. C.: Characterization of subsurface bacteria associated with two shallow aquifers in Oklahoma, Appl. Environ. Microb., 50, 580-588, 1985.

Balogh-Brunstad, Z. and Keller, C. K.: Ectomycorrhizae-mediated biotite weathering and $\mathrm{K}$ uptake (Goldschmidt Conference Abstract), Geochim. Cosmochim. Ac., 74, p. A46, 2010.

Balogh-Brunstad, Z., Keller, C. K., Gill, R. A., Bormann, B. T., and Li, C. Y.: The effect of bacteria and fungi on chemical weathering and chemical denudation fluxes in pine growth experiments, Biogeochemistry, 88, 153-167, 2008.

Barton, H. A. and Northup, D. E.: Geomicrobiology in cave environments: past, current and future perspectives, J. Cave Karst Stud., 69, 163-178, 2007.

Beloin, R. M., Sinclair, J. L., and Ghiorse, W. C.: Distribution and activity of microorganisms in subsurface sediments of a pristine study site in Oklahoma, Microb. Ecol., 16, 85-97, 1988.

Bonkowski, M.: Protozoa and plant growth: the microbial loop in soil revisited, New Phytol., 162, 617-631, 2004.

Borgonie, G., Garcia-Moyano, A., Litthauer, D., Bert, W., Bester, A., van Heerden, E., Moller, C., Erasmus, M., and Onstott, T. C.: Nematoda from the terrestrial deep subsurface of South Africa, Nature, 474, 79-82, 2011.

Bott, M. H. P.: The interior of the Earth: structure and process, Geol. Mag., 108, 555-556, 1971.

Brad, T., Braster, M., van Breukelen, B. M., van Straalen, N. M., and Röling, W. F. M.: Eukaryotic diversity in an anaerobic aquifer polluted with landfill leachate, Appl. Environ. Microb., 74, 3959-3968, 2008.

Brantley, S. L., Goldhaber, M. B., and Ragnarsdottir, K. V.: Crossing disciplines and scales to understand the Critical Zone, Elements, 3, 307-314, 2007.

Bridge, J., Bonneville, S., Saccone, L., Schmalenberger, A., Duran, A., Andrews, M., Hardy, K., Taylor, L., Beerling, D., Benning, L., Leake, J., McMaster, T., and Banwart, S.: Constraining global-scale weathering models through nano-scale ectomycorrhiza-mineral interactions (Goldschmidt Conference Abstract), Geochim. Cosmochim. Ac., 74, p. A123, 2010.

Brockman, F. and Murray, C.: Subsurface microbiological heterogeneity: current knowledge, descriptive approaches and applications, FEMS Microbiol. Rev., 20, 231-247, 1997.

Brons, J. K. and van Elsas, J. D.: Analysis of bacterial communities in soil by use of denaturing gradient gel electrophoresis and 
clone libraries, as influenced by different reverse primers, Appl. Environ. Microb., 74, 2717-2727, 2008.

Buckley, D. H. and Schmidt, T. M.: Exploring the diversity of soil a microbial rain forest, in: Biodiversity of microbial life, edited by: Staley, J. T. and Reysenbach, A., Wiley-Liss, Inc., New York, NY, 183-208, 2002.

Cardenas, E. and Tiedje, J. M.: New tools for discovering and characterizing microbial diversity, Curr. Opin. Biotech., 19, 544-549, 2008.

Castanier, S., Le Métayer-Levrel, G., and Perthuisot, J.-P.: Cacarbonates precipitation and limestone genesis - the microbiogeologist point of view, Sediment. Geol., 126, 9-23, 1999.

Chapelle, F. H., O’Neill, K., Bradley, P. M., Methe, B. A., Ciufo, S. A., Knobel, L. L., and Lovley, D. R.: A hydrogen-based subsurface microbial community dominated by methanogens, Nature, 415, 312-315, 2002.

Chen, Y., Wu, L., Boden, R., Hillebrand, A., Kumaresan, D., Moussard, H., Baciu, M., Lu, Y., and Murrell, J.: Life without light: microbial diversity and evidence of sulfur- and ammonium-based chemolithotrophy in Movile Cave, ISME J., 3, 1093-1104, 2009.

Chivian, D., Brodie, E. L., Alm, E. J., Culley, D. E., Dehal, P. S., DeSantis, T. Z., Gihring, T. M., Lapidus, A., Lin, L.-H., Lowry, S. R., Moser, D. P., Richardson, P. M., Southam, G., Wanger, G., Pratt, L. M., Andersen, G. L., Hazen, T. C., Brockman, F. J., Arkin, A. P., and Onstott, T. C.: Environmental genomics reveals a single-species ecosystem deep within Earth, Science, 322, 275 278, 2008

Chorover, J., Kretzschmar, R., Garcia-Pichel, F., and Sparks, D. L.: Soil biogeochemical processes within the Critical Zone, Elements, 3, 321-326, 2007.

Cunningham, K. I., Northup, D. E., Pollastro, R. M., Wright, W. G., and LaRock, E. J.: Bacteria, fungi and biokarst in Lechuguilla Cave, Carlsbad Caverns National Park, New Mexico, Environ. Geol., 25, 2-8, 1995.

Dalsgaard, T., Thamdrup, B., and Canfield, D.: Anaerobic ammonium oxidation (anammox) in the marine environment, Res. Microbiol., 156, 457-464, 2005.

Dill, B. D., Young, J. C., Carey, P. A., and VerBerkmoes, N. C.: Metaproteomics: techniques and applications, in: Environmental Molecular Microbiology, edited by: Liu, W. T. and Jansson, J. K., Caister Academic Press, 2010.

Drake, H. L., Küsel, K., and Matthies, C.: Acetogenic Prokaryotes, in: The Prokaryotes, edited by: Dworkin, M., Falkow, S., Rosenberg, E., Schleifer, K.-H., and Stackebrandt, E., Springer-Verlag, New York, 354-420, 2006.

Drążkiewicz, M.: Distribution of microorganisms in soil aggregates: effect of aggregate size, Folia Microbiol., 39, 276-282, 1994.

Dumont, M. and Murrell, J.: Stable isotope probing - linking microbial identity to function, Nat. Rev. Microbiol., 3, 499-503, 2005.

Ekelund, F., Ronn, R., and Christensen, S.: Distribution with depth of protozoa, bacteria and fungi in soil profiles from three Danish forest sites, Soil Biol. Biochem., 33, 475-481, 2001.

Ekendahl, S., O'Neill, A. H., Thomsson, E., and Pedersen, K.: Characterisation of yeasts isolated from deep igneous rock aquifers of the Fennoscandian Shield, Microb. Ecol., 46, 416428, 2003.

Elhottová, D., Krištùfek, V., Frouz, J., Nováková, A., and
Chroòáková, A.: Screening for microbial markers in Miocene sediment exposed during open-cast brown coal mining, Antonie Van Leeuwenhoek, 89, 459-463, 2006.

Ellis, B. K., Stanford, J. A., and Ward, J. V.: Microbial assemblages and production in alluvial aquifers of the Flathead River, Montana, USA, J. N. Am. Benthol. Soc., 17, 382-402, 1998.

Emerson, D. and Moyer, C.: Isolation and characterization of novel iron-oxidizing bacteria that grow at circumneutral $\mathrm{pH}$, Appl. Environ. Microb., 63, 4784-4792, 1997.

Engel, A. S., Lee, N., Porter, M. L., Stern, L. A., Bennett, P. C., and Wagner, M.: Filamentous "Epsilonproteobacteria" dominate microbial mats from sulfidic cave springs, Appl. Environ. Microb., 69, 5503-5511, 2003.

Engel, A. S., Porter, M. L., Stern, L. A., Quinlan, S., and Bennett, P. C.: Bacterial diversity and ecosystem function of filamentous microbial mats from aphotic (cave) sulfidic springs dominated by chemolithoautotrophic "Epsilonproteobacteria", FEMS Microbiol. Ecol., 51, 31-53, 2004.

Ettwig, K. F., Butler, M. K., Le Paslier, D., Pelletier, E., Mangenot, S., Kuypers, M. M. M., Schreiber, F., Dutilh, B. E., Zedelius, J., de Beer, D., Gloerich, J., Wessels, H. J. C. T., van Alen, T., Luesken, F., Wu, M. L., van de Pas-Schoonen, K. T., Op den Camp, H. J. M., Janssen-Megens, E. M., Francoijs, K.-J., Stunnenberg, H., Weissenbach, J., Jetten, M. S. M., and Strous, M.: Nitrite-driven anaerobic methane oxidation by oxygenic bacteria, Nature, 464, 543-548, 2010.

Farnleitner, A. H., Wilhartitz, I., Ryzinska, G., Kirschner, A. K. T., Stadler, H., Burtscher, M. M., Hornek, R., Szewzyk, U., Herndl, G., and Mach, R. L.: Bacterial dynamics in spring water of alpine karst aquifers indicates the presence of stable autochthonous microbial endokarst communities, Environ. Microbiol., 7, 12481259, 2005.

Finlay, B. J. and Fenchel, T.: Protozoan community structure in a fractal soil environment, Protist, 152, 203-218, 2001.

Fliermans, C. B.: Microbial life in the terrestrial subsurface of southeastern coastal plain sediments, Hazard. Waste Hazard., 6, 155-171, 1989.

Fontaine, S., Mariotti, A., and Abbadie, L.: The priming effect of organic matter: a question of microbial competition?, Soil Biol. Biochem., 35, 837-843, 2003.

Fredrickson, J. K., McKinley, J. P., Bjornstad, B. N., Long, P. E., Ringelberg, D. B., White, D. C., Krumholz, L. R., Suflita, J. M., Colwell, F. S., Lehman, R. M., Phelps, T. J., and Onstott, T. C.: Pore-size constraints on the activity and survival of subsurface bacteria in a late cretaceous shale-sandstone sequence, northwestern New Mexico, Geomicrobiol. J., 14, 183-202, 1997.

Gadd, G. M. and Raven, J. A.: Geomicrobiology of eukaryotic microorganisms, Geomicrobiol. J., 27, 491-519, 2010.

Ghiorse, W. C. and Wilson, J. T.: Microbial ecology of the terrestrial subsurface, in: Advances in Applied Microbiology, edited by: Allen, I. L., Academic Press, 33, 107-172, 1998.

Gold, T.: The deep, hot biosphere, P. Natl. Acad. Sci. USA, 89, 6045-6049, 1992.

Göttlich, E., van der Lubbe, W., Lange, B., Fiedler, S., Melchert, I., Reifenrath, M., Flemming, H.-C., and de Hoog, S.: Fungal flora in groundwater-derived public drinking water, Int. J. Hyg. Envir. Heal., 205, 269-279, 2002.

Gounot, A. M.: Microbial ecology of groundwaters, in: Groundwater Ecology, edited by: Gibert, J., Danielopol, D. L., and Stan- 
ford, J. A., Academic Press, San Diego, CA, 189-215, 1994.

Griebler, C. and Lueders, T.: Microbial biodiversity in groundwater ecosystems, Freshwater Biol., 54, 649-677, 2009.

Griffiths, B.: Microbial-feeding nematodes and protozoa in soil: Their effectson microbial activity and nitrogen mineralization in decomposition hotspots and the rhizosphere, Plant Soil, 164, 2533, 1994.

Grossart, H.-P., Dziallas, C., Leunert, F., and Tang, K. W.: Bacteria dispersal by hitchhiking on zooplankton, P. Natl. Acad. Sci. USA, 107, 11959-11964, 2010.

Haldeman, D. L., Amy, P. S., Ringelberg, D., and White, D. C.: Characterization of themicrobiology within a $21 \mathrm{~m}^{3}$ section of rock from the deep subsurface, Microb. Ecol., 26, 145-159, 1993.

Hazen, T., Jiménez, L., López de Victoria, G., and Fliermans, C.: Comparison of bacteria from deep subsurface sediment and adjacent groundwater, Microb. Ecol., 22, 293-304, 1991.

Hinsinger, P., Bengough, A., Vetterlein, D., and Young, I.: Rhizosphere: biophysics, biogeochemistry and ecological relevance, Plant Soil, 321, 117-152, 2009.

Hirsch, P. and Rades-Rohkohl, E.: Microbial colonization of aquifer sediment exposed in a groundwater well in northern Germany, Appl. Environ. Microb., 56, 2963-2966, 1990.

Holmström, S., Norström, S., and Rosling, A.: Production of metal chelating ligands by soil horizon specific ectomycorrhizal fungus (Goldschmidt Conference Abstract), Geochim. Cosmochim. Ac., 74, p. A414, 2010.

Hugenholtz, P., Goebel, B., and Pace, N.: Impact of cultureindependent studies on the emerging phylogenetic view of bacterial diversity, J. Bacteriol., 180, 4765-4774, 1998.

Jackson, R. B., Moore, L. A., Hoffmann, W. A., Pockman, W. T., and Linder, C. R.: Ecosystem rooting depth determined with caves and DNA, P. Natl. Acad. Sci. USA, 96, 11387-11392, 1999.

Jarvis, N. J.: A review of non-equilibrium water flow and solute transport in soil macropores: principles, controlling factors and consequences for water quality, Eur. J. Soil Sci., 58, 523-546, 2007.

Jin, L., Ravella, R., Ketchum, B., Bierman, P. R., Heaney, P., White, T., and Brantley, S. L.: Mineral weathering and elemental transport during hillslope evolution at the Susquehanna/Shale Hills Critical Zone Observatory, Geochim. Cosmochim. Ac., 74, 3669-3691, 2010.

Kashefi, K.: Extending the upper temperature limit for life, Science, 301, 934-934, 2003.

Kieft, T. L., Amy, P. S., Brockman, F. J., Fredrickson, J. K., Bjornstad, B. N., and Rosacker, L. L.: Microbial abundance and activities in relation to water potential in the vadose zones of arid and semiarid sites, Microb. Ecol., 26, 59-78, 1993.

Kim, Y. J., Lee, H. S., Kim, E. S., Bae, S. S., Lim, J. K., Matsumi, R., Lebedinsky, A. V., Sokolova, T. G., Kozhevnikova, D. A., Cha, S.-S., Kim, S.-J., Kwon, K. K., Imanaka, T., Atomi, H., Bonch-Osmolovskaya, E. A., Lee, J.-H., and Kang, S. G.: Formate-driven growth coupled with $\mathrm{H}_{2}$ production, Nature, 467, 352-355, 2010.

Kohlmeier, S., Smits, T. H. M., Ford, R. M., Keel, C., Harms, H., and Wick, L. Y.: Taking the fungal highway: mobilization of pollutant-degrading bacteria by fungi, Environ. Sci. Technol., 39, 4640-4646, 2005.
Kowalchuk, G. A. and Stephen, J. R.: Ammonia-oxidizing bacteria: a model for molecular microbial ecology, Annu. Rev. Microbiol., 55, 485-529, 2001.

Krauss, G., Sridhar, K. R., Jung, K., Wennrich, R., Ehrman, J., and Bärlocher, F.: Aquatic hyphomycetes in polluted groundwater habitats of Central Germany, Microb. Ecol., 45, 329-339, 2003.

Krauss, G., Sridhar, K. R., and Bärlocher, F.: Aquatic hyphomycetes and leaf decomposition in contaminated groundwater wells in Central Germany, Fund. Appl. Limnol., 162, 416428, 2005.

Krumholz, L. R.: Microbial communities in the deep subsurface, Hydrogeol. J., 8, 4-10, 2000.

Krumholz, L. R., McKinley, J. P., Ulrich, G. A., and Suflita, J. M.: Confined subsurface microbial communities in Cretaceous rock, Nature, 386, 64-66, 1997.

Kuehn, K. A. and Koehn, R. D.: A mycofloral survey of an artesian community within the Edwards Aquifer of Central Texas, Mycologia, 80, 646-652, 1988.

Kurakov, A., Lavrent'ev, R., Nechitailo, T., Golyshin, P., and Zvyagintsev, D.: Diversity of facultatively anaerobic microscopic mycelial fungi in soils, Microbiology, 77, 90-98, 2008.

Küsel, K. and Drake, H. L.: Acetate synthesis in soil from a bavarian beech forest., Appl. Environ. Microb., 60, 1370-1373, 1994.

Küsel, K. and Drake, H.: Effects of environmental parameters on the formation and turnover of acetate by forest soils, Appl. Environ. Microb., 61, 3667-3675, 1995.

Küsel, K., Wagner, C., Trinkwalter, T., Gößner, A. S., Bäumler, R., and Drake, H. L.: Microbial reduction of Fe(III) and turnover of acetate in Hawaiian soils, FEMS Microbiol. Ecol., 40, 73-81, 2002.

Lara, E., Berney, C., Ekelund, F., Harms, H., and Chatzinotas, A.: Molecular comparison of cultivable protozoa from a pristine and a polycyclic aromatic hydrocarbon polluted site, Soil Biol. Biochem., 39, 139-148, 2007.

Lin, H.: Earth's Critical Zone and hydropedology: concepts, characteristics, and advances, Hydrol. Earth Syst. Sci., 14, 25-45, doi:10.5194/hess-14-25-2010, 2010.

Lin, L.-H., Wang, P.-L., Rumble, D., Lippmann-Pipke, J., Boice, E., Pratt, L. M., Lollar, B. S., Brodie, E. L., Hazen, T. C., Andersen, G. L., DeSantis, T. Z., Moser, D. P., Kershaw, D., and Onstott, T. C.: Long-term sustainability of a high-energy, low-diversity crustal biome, Science, 314, 479-482, 2006.

Loquay, N., Wylezich, C., and Arndt, H.: Composition of groundwater nanoprotist communities in different aquifers based on aliquot cultivation and genotype assessment of cercomonads, Fund. Appl. Limnol., 174, 261-269, 2009.

Madigan, M., Martinko, J., and Parker, J.: Brock biology of microorganisms, Prentice Hall, 2000.

Madsen, E. L.: Environmental Microbiology: From Genomes to Biogeochemistry, 1 ed., Wiley-Blackwell, Oxford, UK, 2008.

Malloch, D. W., Pirozynski, K. A., and Raven, P. H.: Ecological and evolutionary significance of mycorrhizal symbioses in vascular plants (a review), P. Natl. Acad. Sci. USA, 77, 2113-2118, 1980.

Manefield, M., Whiteley, A. S., Griffiths, R. I., and Bailey, M. J.: RNA stable isotope probing, a novel means of linking microbial community function to Phylogeny, Appl. Environ. Microb., 68, 5367-5373, 2002.

Miltner, A., Richnow, H.-H., Kopinke, F.-D., and Kästner, M.: Assimilation of $\mathrm{CO}_{2}$ by soil microorganisms and transformation 
into soil organic matter, Org. Geochem., 35, 1015-1024, 2004.

Miltner, A., Kopinke, F.-D., Kindler, R., Selesi, D., Hartmann, A., and Kästner, M.: Non-phototrophic $\mathrm{CO}_{2}$ fixation by soil microorganisms, Plant Soil, 269, 193-203, 2005.

Northup, D. and Lavoie, K.: Geomicrobiology of caves: a review, Geomicrobiol. J., 18, 199-222, 2001.

Northup, D. E., Barns, S. M., Yu, L. E., Spilde, M. N., Schelble, R. T., Dano, K. E., Crossey, L. J., Connolly, C. A., Boston, P. J., Natvig, D. O., and Dahm, C. N.: Diverse microbial communities inhabiting ferromanganese deposits in Lechuguilla and Spider Caves, Environ. Microbiol., 5, 1071-1086, 2003.

Novarino, G., Warren, A., Kinner, N. E., and Harvey, R. W.: Protists from a sewage-contaminated aquifer on Cape Cod, Massachusetts, Geomicrobiol. J., 12, 23-36, 1994.

Novarino, G., Warren, A., Butler, H., Lambourne, G., Boxshall, A., Bateman, J., Kinner, N. E., Harvey, R. W., Mosse, R. A., and Teltsch, B.: Protistan communities in aquifers: a review, FEMS Microbiol. Rev., 20, 261-275, 1997.

National Research Council (NRC): Basic research opportunities in earth science, National Academy Press, Washington DC, USA, 2001.

O’Connell, S. P., Lehman, R. M., Snoeyenbos-West, O., Winston, V. D., Cummings, D. E., Watwood, M. E., and Colwell, F. S.: Detection of Euryarchaeota and Crenarchaeota in an oxic basalt aquifer, FEMS Microbiol. Ecol., 44, 165-173, 2003.

Onstott, T. C., Moser, D. P., Pfiffner, S. M., Fredrickson, J. K., Brockman, F. J., Phelps, T. J., White, D. C., Peacock, A., Balkwill, D., Hoover, R., Krumholz, L. R., Borscik, M., Kieft, T. L., and Wilson, R.: Indigenous and contaminant microbes in ultradeep mines, Environ. Microbiol., 5, 1168-1191, 2003.

Pace, N. R.: A molecular view of microbial diversity and the biosphere, Science, 276, 734-740, 1997.

Pašić, L., Kovèe, B., Sket, B., and Herzog-Velikonja, B.: Diversity of microbial communities colonizing the walls of a Karstic cave in Slovenia, FEMS Microbiol. Ecol., 71, 50-60, 2010.

Pedersen, K.: The deep subterranean biosphere, Earth-Sci. Rev., 34, 243-260, 1993.

Pedersen, K.: Microbial life in deep granitic rock, FEMS Microbiol. Rev., 20, 399-414, 1997.

Pedersen, K.: Exploration of deep intraterrestrial microbial life: current perspectives, FEMS Microbiol. Lett., 185, 9-16, 2000.

Pfiffner, S. M., Cantu, J. M., Smithgall, A., Peacock, A. D., White, D. C., Moser, D. P., Onstott, T. C., and van Heerden, E.: Deep subsurface microbial biomass and community structure in Witwatersrand Basin mines, Geomicrobiol. J., 23, 431-442, 2006.

Price, P. B. and Sowers, T.: Temperature dependence of metabolic rates for microbial growth, maintenance, and survival, P. Natl. Acad. Sci. USA, 101, 4631-4636, 2004.

Radajewski, S., Webster, G., Reay, D. S., Morris, S. A., Ineson, P., Nedwell, D. B., Prosser, J. I., and Murrell, J. C.: Identification of active methylotroph populations in an acidic forest soil by stableisotope probing, Microbiology, 148, 2331-2342, 2002.

Rastogi, G., Stetler, L., Peyton, B., and Sani, R.: Molecular analysis of prokaryotic diversity in the deep subsurface of the former Homestake gold mine, South Dakota, USA, J. Microbiol., 47, 371-384, 2009.

Robinson, B. S., Bamforth, S. S., and Dobson, P. J.: Density and diversity of protozoa in some arid Australian soils, J. Eukaryot. Microbiol., 49, 449-453, 2002.
Rusterholtz, K. J. and Mallory, L. M.: Density, activity, and diversity of bacteria indigenous to a karstic aquifer, Microb. Ecol., 28, 79-99, 1994.

Rusznyák, A., Akob, D. M., Nietzsche, S., Eusterhues, K., Totsche, K., Neu, T., Frosch, T., Popp, J., Keiner, R., Geletneky, J., Katzschmann, L., Schulze, E.-D., and Küsel, K.: Calcite biomineralization by bacterial isolates from the recently discovered pristine karstic Herrenberg cave, Appl. Environ. Microb., in press, 2011.

Sarbu, S. M., Kane, T. C., and Kinkle, B. K.: A chemoautotrophically based cave ecosystem, Science, 272, 1953-1955, 1996.

Schmalenberger, A., Duran, A., Romero-Gonzalez, M., Leake, J., and Banwart, S.: Oxalic acid release in ectomycorrhiza mineral weathering (Goldschmidt Conference Abstract), Geochim. Cosmochim. Ac., 74, p. A923, 2010.

Solé, M., Chatzinotas, A., Sridhar, K. R., Harms, H., and Krauss, G.: Improved coverage of fungal diversity in polluted groundwaters by semi-nested PCR, Sci. Total Environ., 406, 324-330, 2008.

Stevens, T.: Lithoautotrophy in the subsurface, FEMS Microbiol. Rev., 20, 327-337, 1997.

Strauss, E. A. and Dodds, W. K.: Influence of protozoa and nutrient availability on nitrification rates in subsurface sediments, Microb. Ecol., 34, 155-165, 1997.

Takai, K., Moser, D. P., DeFlaun, M., Onstott, T. C., and Fredrickson, J. K.: Archaeal diversity in waters from deep South African gold mines, Appl. Environ. Microb., 67, 5750-5760, 2001.

Torsvik, V., Ovreas, L., and Thingstad, T.: Prokaryotic diversitymagnitude, dynamics, and controlling factors, Science, 296, 1064-1066, 2002.

van Schöll, L., Kuyper, T., Smits, M., Landeweert, R., Hoffland, E., and Breemen, N.: Rock-eating mycorrhizas: their role in plant nutrition and biogeochemical cycles, Plant Soil, 303, 3547, 2008.

Vartoukian, S. R., Palmer, R. M., and Wade, W. G.: Strategies for culture of "unculturable" bacteria, FEMS Microbiol. Lett., 309, 1-7, 2010.

Wall, D. H., Bardgett, R. D., and Kelly, E.: Biodiversity in the dark, Nat. Geosci., 3, 297-298, 2010.

Wang, J., Wu, Y., Jiang, H., Li, C., Dong, H., Wu, Q., Soininen, J., and Shen, J.: High beta diversity of bacteria in the shallow terrestrial subsurface, Environ. Microbiol., 10, 2537-2549, 2008.

Whitman, W., Coleman, D., and Wiebe, W.: Prokaryotes: The unseen majority, P. Natl. Acad. Sci. USA, 95, 6578-6583, 1998.

Wilson, J. T., McNabb, J., Balkwill, D. L., and Ghiorse, W. C.: Enumeration and characterization of bacteria indigenous to a shallow water-table aquifer, Ground Water, 21, 134-142, 1983.

Wright, D. A., Killham, K., Glover, L. A., and Prosser, J. I.: The effect of location in soil on protozoal grazing of a genetically modified bacterial inoculum, Geoderma, 56, 633-640, 1993.

Young, I. M.: Microhabitats, in: Encyclopedia of soil science, edited by: Chesworth, W., Springer, 450-452, 2008.

Young, I. M. and Ritz, K.: Tillage, habitat space and function of soil microbes, Soil Till. Res., 53, 201-213, 2000. 